\title{
Intentional Specificity of the Emotive Hortative Statements
}

\author{
Alina Yu. Maslova \\ Faculty of Philology \\ Ogarev Mordovia State University \\ Saransk, Russian Federation \\ e-mail: al_mas@mail.ru
}

\begin{abstract}
The article identifies the causative mechanisms of interaction between the hortative and emotive meanings, as well as specificity of the explicit and implicit implementation of intentional meanings on communicative level and semanticpragmatic level that make up the content plane of the emotive and hortative statements.
\end{abstract}

Keywords-emotive hortative statement; intention; explicit; implicit; communicative and semantic; communicative and pragmatic

\section{INTRODUCTION}

The pattern of intention is represented by the content plane of the emotive hortative statements (EHS), which is thought of as a system of incentive and emotive meanings encoded by a set of verbal and non-verbal means, belonging to different levels of language and performing single communicative function, which is to motivate the listener to commit / abstain from an action or to change / keep the condition in the situation of emotive hortation [1].

The interpretation specificity of the communicative goal of the EHS is determined by their multi-dimensional structure, as far as the intentional model of the EHS is a combination of the hortative macro-intention and the emotive micro-intention. The difficulty in defining the role of the emotive component in the hortative statement is that emotionality, on the one hand, integrates different meanings and demonstrates the variability of their use depending on the parameters of the situation of communication, and on the other hand, it is a condition for implementing the statement, the motivating force, which directs and controls the process of communication. Consequently, the EHS are noted for their communicative and semantic, as well as communicative and pragmatic "multilayered" nature.

\section{The CommunicATIVE AND SEMANTIC SPECIFICITY OF THE EMOTIVE HORTATIVE STATEMENT}

From the communicative and semantic point of view, the structure of the EHS includes the hortative and emotive meanings. Specificity of the interaction of meanings is the following: 1) in the combination of communicative purposes, 2) in the method of expression of the hortative intention.

1) The hortative and emotive meanings of the EHS represent the following types of combinations:
a)Integration, when the emotive information repeats, "reduplicates", enhances the hortative meaning:

- Ne pori čuš! Otvali, tjotja! (D. Doncova). Ne šej mne delo, načal'nik! (T. Ustinova).

- Do not drivel! Shove off, auntie! (D. Doncova). Do not trump a case for me, chief! (T. Ustinova).

b) Differentiation, when the hortative meaning is the macrointention and the emotive meaning forms the micro-intention to act as a supplementary, secondary meaning, which explains, argues, makes up for the missing information and programming the perlocutionary effect:

- Babulečka Sonečka, pomogi Hrista radi! (D. Doncova).

-Grammy Sonechka, help for Christ's sake! (D. Doncova).

The singled out emotive components explicate the attitude of the speaker to the listener (a term of endearment: grammy Sonechka) or focus on the need to execute the request (for Christ's sake).

2) Based on the way of expressing intention of motivation the EHS can be divided into explicit (production and communication of the statement, in which its illocutionary force is expressed directly) and implicit (the intentional meaning of the statement is expressed indirectly by interpreting the emotive content).

The explicit expression of the hortative macro-intention in the situation of the emotive hortation reflects the direct hortation of the receiver to act. In such cases, the interaction of the hortative and the emotive meanings is carried out on the basis of mechanisms of coordination (duplication) and supplement (compensation) (according to the terminology by S. Ionova [2]).

The mechanism of coordination (duplication) between the hortative and the emotive meanings is in repetition, enhancement or modifying the hortative meaning through the emotive one. It is manifested in the communicative structures, characterized by:

Syncretism of the expressed meanings as the emotive meaning repeats (doubles) the hortative one to cause an enhancement in the illocutionary force of a statement due to the integrated illocutionary and perlocutionary performance of the hortative and the emotive components of the macro act:

- Zatknis! Duj domoj! Kyš otsjuda! Ne goni purgu! (D. Doncova).

- Shut up! Dash home! Shoo away! Do not give me that crap! (D. Doncova).

- Representation of the emotionally marked type of hortation, while maintaining the communication topic: 
- Ne ubivajte Mirru... (request) < .. > Umoljaju! (request and plea) (D. Doncova).

- Don't kill Mirra ... (request) <...> I beg you! (request and plea) (D. Doncova).

This example shows the coordination of the emotive and the hortative meanings as part of fulfillment of the basic illocutionary goal, which manifests in increased intensity of impact and is reflected in the communicative and pragmatic options of hortation: in the first case, it is the request, in the second case of a mitigated hortation, it is a plea of a major impact.

Let us compare between:

- Sobirajtes' pobystreje, - poprosil Hohlov (request). $<\ldots>$ Davaj, davaj, ševelites’! (T. Ustinova) (requirement);

- Get ready quickly, - Khokhlov asked (request). <...> Come on, come on, move! (T. Ustinova) (requirement);

- Klara, peresjad' $k$ pape! (request) <... Klara, ty sejčas vstajoš I sadišsja rjadom s papoj! - razdraženno skazala mama (T. Ustinova) (requirement).

- Clara, please take a seat next to your father! (request) <...> Clara, you now get up and sit down next to your father! - Mom said irritably (T. Ustinova) (requirement).

These examples illustrate the coordination between the hortative and the emotive meanings, which is a modification of the hortative meaning: a request is transformed into a requirement. Thus, an increase of flatness is observed due to the redistribution in the role positions of communicants while maintaining the communication topic.

The mechanism of communicative and pragmatic supplement (compensation) of the hortative meaning by the emotive one is characterized by adding up of new information into the statement to clarify, supplement, specify, etc. the hortative information:

- Prosti! Ja vorovka! Merzavka! Ukrala den'gi! Davaj den'gi, a ne to prišju! (D. Doncova)

- Sorry! I am a thief! I'm a jerk! I've stolen the money! Give me the money or I blow you out! (D. Doncova)

In the given examples the motivation is verbalized by a verb in the imperative form and the emotive components act as supplementary means of impact on the emotions of the receiver in order to manipulate the receiver to reach the basic goal.

The pragmatic value of the emotive components in the structure of hortation may be referred to as a justification of what the sender asks:

- Doktor, pro vas tut vse govorjat, čto vy ponimajuščij!.. Naš hozjain tak skazal! Vy jego operirovali, tak on govorit, čto vy vsjo možete! Vylečite mat', doktor! Hristom Bogom Vas prošu! Hotite, na koleni vstanu?! (T. Ustinova).

- Doctor, everybody says that you are a knowing man!.. Our master said so! You performed an operated on him, so he says that you can do everything! Fix up my mother, doctor! I pray you for God's sake! Do you want me to drop on my knees?! Ustinova).

The emotional markers of the situation of hortation is caused by the state of mental imbalance of the addresser (fear for the life of a significant other). The intention of the addresser to cause the receiver to induce a specific action (fix up) is added up with the intention to influence the psycho-emotional sphere of the receiver in order to simulate the emotional situation that could cause a corresponding emotional response. Targeting for achieving the intentional emotional effect is reflected in the emotional relationship to the receiver, the emotional evaluation of both the professional abilities (you can do everything) and the human qualities (knowing man). Speaker increases the role status of the receiver and emphasizes own dependence on the latter hoping for his generosity (do you want me to drop on my knees?). The structure with the phraseological meaning to pray for God's sake acts as a powerful emotional amplifier of the impact, due to its metaphorical nature and the markers of the emotive meaning in the culture of the native speakers. The addresser underlines the importance of the action by carrying out such an impact.

Thus, the given mechanism is a differentiated interaction of the hortative and emotive components of the considered macro act: the pragmatic role of the emotive component in the statements of this type is to solve the perlocutionary problem.

The implicit expression of the hortative intention is related to the concept of an indirect speech act, which presumes a rethinking of the primary (literally) and the secondary (implicit) communicative meaning of the statement. The implicit method of expressing intention is a hidden impact on the recipient in order to achieve a perlocutionary effect, which occurs when "... one illocutionary act is carried out through the implementation of the other" [3]. The encoding of information in a particular situation of communication is often caused by intention of the addresser to manipulate the receiver to perform a certain activity, which is needed for the addresser him/herself. The forefront in this process is taken by the role and personal relationships between the communicants, committed to delivering actional, mental or emotional perlocutionary effect. The statements of this type put in action the interaction of the hortative and emotive meanings through the communicative and pragmatic replacement of the hortative mechanism by the emotive one. The principle of operation of the emotive intentional meaning in the situation of the hidden hortation we designate as implicitly-manipulative.

The replacement of the hortative intention by the emotive one in the indirect EHS is caused by the specific intentional emotive meanings, which generate more complex intentional structures: expression of emotional state and emotional attitude toward a particular receiver, are the ways of persuasion and depending on situational factors program achieving various perlocutionary goals, in particular, goals of hortation by means of situational rethinking of the emotive meaning. The implicit transmission of the hortative intention involves manipulation of the listener, which is carried out by the impact on the listener's mentality and emotions. It provides the ability to interpret the communicative information: take the initiative, that is, to take a decision to act in the absence of direct orders or not to act, leaving the order unattended. Indirect EHS are specific for their pragmatic "multilayered" nature. Their interpretation is caused by a set of situational factors, which determine the communicative interaction of the speaker and the listener to influence the success of the implicit implementation of the hortation.

Let us illustrate the possible intentional models of the communicative interaction of the addresser and the receiver in a situation of the indirect emotive hortation.

1. Manipulation of the listener on a mental and emotional level. The speaker does not impose the listener the target to induce the listener to some action. The speaker seeks to bring the 
listener to perform some action. Such a hortation directs the receiver to fulfill the goal, while there is an impression that the receiver acts independently. The success of the impact is caused by the speaker's intention to affect the emotional state of the listener, for example, make the listener laugh, get angry, shock, unbalance, etc. using

a) Explication of the emotional state of the speaker:

- Bred kakoj-to! U menja iz-za tebja golova idet krugom! (T. Garmash-Roffe)

- This is so rubbish! My head is spinning because of you! (T. Garmash-Roffe)

(Implication: Let us finish this conversation). The addresser informs the receiver on the own poor mental and emotional state. The potentially underlying implication is restored by the means of the communicative and logical conclusion about the impossibility to continue the action because of malaise;

b) Explication of the emotional relationship (evaluation), i.e the stimulation to continue action using the words of praise or compliment, and so on or the termination of undesired actions by the communicant through the expression of subjective perceptions and subjective qualification of the surrounding:

- Čto za jerundu Vy nesjote, Irina Nikolajevna! - skazal Andrej s dosadoj (T. Ustinova).

- What a nonsense you are telling, Irina Nikolaevna! Andrey said with annoyance (T. Ustinova).

(Implication: Stop saying this).

Communicative intention of the addresser is associated with the desire to influence the behavior of the recipient, to change the status quo. Emotional manipulation is carried out by the expression of the emotional evaluation to tell nonsense, which involves a demand for the partner to change the strategy of communication.

2. Building up a certain environment of communication. The speaker usually seeks to create a socially pleasant atmosphere to suggest the listener to perform the expected action, to encourage its rapid implementation. The environment provoking the conflicting communication can be created, which sometimes contributes to a more effective implementation of hortation. An implicit transmission of the hortative meaning by expressing the emotive meaning allows, for example, offsetting the flatness or, on the contrary, enhancing it; mitigating the conflict situation by preventing the embarrassment if the listener refuses to perform an action, or to update the execution of hortation by the speaker's demonstration of the own negative attitude, and so on.

- Ne budete li vy stol' ljubezny pokorrektneje sformulirovat' svoj vopros? - sladko ulybajas', sprosil Igor (A. Eksler).

- Would you be so kind to ask your question in a more correct form? - Igor asked smiling sweetly (A. Eksler).

The question in the meaning of hortation is a typical example of implementation of indirect hortation. Negation is used to implement the rules of politeness by expression of an unobtrusive request to focus on creation of a comfortable environment for communication. The speaker is as of emphasizing dependence on the action performer to leave the latter the right to choose: to react or not to respond to expression.

- Nam by pogovorit’? - smuščajas', skazal on (T. Ustinova).

- Tan', a možet, ne nado, a? - zaskulila ona (T. Ustinova).

- We must talk, mustn't we? - He said in embarrassment (T. Ustinova).
- Tanya, you probably should not do this, huh? - She whined (T. Ustinova).

There is a request for the information on the possibility or authorization to perform an action in such statements, which increases the role status of the listener. I. Shatunovsky marks that such type of a question can be treated as a potentially compressed chain of speech acts, which express a request, with the request has a conventional nature [4].

Interrogative constructions with modal marker to want are treated similarly:

- Hotite, ja oformklju zakaz prjamo sejčas? - zaiskivajšče progovorila ona (T. Ustinova).

- Do you want me to place the order right now? - She said ingratiatingly (T. Ustinova).

An actualized role status of the listener, its role priority is noted. Addresser demonstrates the attitude, signals that initiates actions in the interests of the receiver, but recognizes the right of the latter to choose to fulfill it or to refuse.

The speaker in the given illustrations builds relationships with the listener based on the positive emotions: by demonstrating friendly attitude to the interlocutor, looking for maximum openness of the latter.

There is a reverse pattern when the speaker builds relationships in a negative emotional pattern. For example:

- Čto vy delajete? - voskliknula ona (D. Doncova). (Implication: Stop doing this).

- Gde vas čerti nosjat? - zaoral on (D. Doncova). (Implication: Get to work).

- What are you doing? - She exclaimed (D. Doncova). (Implication: Stop doing this).

- Where the hell are you? - He yelled (D. Doncova). (Implication: Get to work).

Such emotive patterns create stress in maintaining social balance and giving communication a conflict character. The receiver indicates negative emotional state (irritation, discontent) and, based on the wider context, implicitly encourages not only to perform an action, but to do it immediately. Thus, the increase in flatness of hortation is based on the negative emotions of the speaker. This suggests that the non-action will be followed by an even more negative attitude to the receiver.

3. Modeling of the verbal behavior by a receiver. In a situation of dialogue the speaker often emphasizes the own social or situational role status, experience and competence. Such selfactualization of the speaker assumes the appropriate behavior of the listener and predicts the expected behavior:

- Kak ty s materju razgovarivaješ? (T. Ustinova).

- How dare you talking with your mother in such manner? (T. Ustinova).

(Implication: Change your line of behavior).

- Kira, - prikriknul Kostik, - ja tvoj načal'nik, a ne naoborot! Kak ja rešu, tak vsjo I budet! (T. Garmash-Roffe).

- Kira - Kostya raised his voice - I'm your boss, it is not the other way round! I decide and so be it! (T. Garmash-Roffe).

(Implication: Do not argue with me).

Communicating the status of the speaker is aimed to emphasize that the addresser does not allow a choice on the part of the receiver, as the hortation comes from a person with a higher social status. 
- Ješčo raz ob’jasnjaju! Eto ne vhodit v moji dolžnostnyje objazannosti! (T. Ustinova).

- I explain once again! It's not the part of my function!

(T. Ustinova).

(Implication: Leave me alone).

The indication on function implies the intention of the speaker to stop unwanted contact.

- V žizni jǔčo I ne takoje byvajet! Rano sljozy lit’! (D. Doncova).

- It is all in a life time! It is too early to cry buckets! (D. Doncova).

(Implication: Calm down).

In these illustrations indirect expression of hortation is based on explication of experience and worldly wisdom by the speaker.

Therefore, as seen from the examples, the adoption of the role position of the speaker leads to revision of position by the listener to take the side of the speaker.

4. Self-identification of the addresser. The desire of the speaker for self-determination is carried out, usually, by indication on the affiliation to a particular social group (e.g. through the slang or industry words) to a particular social environment (e.g. through the colloquialisms, dialects and so on), to a national, historical or cultural environment (e.g. through phraseological structures or precedent texts), and so on. Based on the solidarity formula "a friend among friends" or the denial formula "a stranger among strangers" the speaker tends to use, the manipulation of consciousness of receiver is carried out and the implicit transmission of the hortative intention is implemented:

- On tak na menja kričal, ty sebe ne predstavljaješ! žalujetsja Olga. - Nu I čto? A Vas'ka slušajet da jest! (D. Doncova).

- He yelled at me so much, you have no idea! - Olga complains. - So what? I turned a deaf ear on it! (D. Doncova).

(Implicature: Pay no attention).

In these illustrations implicit transmission of the hortative intentions is caused by the address of the speaker to the national and cultural speech experience of the communicators: the linguistic competence of the speaker reflects the ability to disguise the communicative purpose, while the speech competence of the listener reflects the ability to interpret the statement in accordance with the communicative intention of the speaker.

- Predki tebe plohogo ne želajut, - vazrazila mama (D. Doncova).

- 'Rents wish you no bad, - my mother opposed (D. Doncova).

(Implication: Obey your parents).

In the present illustration slang lexicon reflects the desire of the speaker to show the listener that they "speak the same language", that is, the addresser when expressing intentions chooses the elements, which mark the statement as recognizable to members of this community, and thus provides reaching the communicative goal.

The above intentional interaction models of communicants belong to a situation of indirect emotive hortation.

Thus, the indirect mechanism of hortation, which is implemented by means of explication of emotional information, is the emotional impact, which is directed to program the interpretation of the receiver in a desired direction for the addresser. By means of indirect expression of intentions, the addresser tries to disguise the primary illocutionary goal of the statement, to elevate the communicative status of the receiver and to provide an opportunity to take a decision on the action in the absence of direct order to do it.

\section{The COMmunicATIVE AND PRAGMATIC SPECIFICITY OF THE EMOTIVE HORTATIVE STATEMENT}

From the communicative and pragmatic point of view, the basic and the supplementary impacts can be distinguished. The basic impact in the EHS should be considered the impact, aimed at the implementation of the hortative macro-intention. The role of the supplementary impact is reduced to organization of interaction of communicators needed to achieve the perlocutionary effect. For example, it is a creation of a special environment for communication:

- Hvatit vypendrivat'sja, živo govori, čto ty znaješ! - Jesli ješčo raz ustroiš isteriku, zakaprizničaješ, kak izbalovannaja devčonka, ja vyzovu sjuda Degtjarjova. Pover', Aleksandr Mihajlovič master doprosov, on vytjanet iz tebja vsjo nužnoje I nenužnoje (D. Doncova).

- Stop showing off, tell me quickly what you know! - If you pitch a fit once again or you act up like a spoiled little girl, I'll call for Degtyarev to come here. Believe me, Alexander Mikhailovich is an expert in interrogation, he will pull out of you all he needs and even what he does not need (D. Doncova).

As illustrated, the basic impact is directed on provoking hortation. It is expressed in the request (tell me). The supplementary impact, which is represented as a threat (I'll call for Degtyarev to come here), is focused on the modeling of emotional situation to induce certain emotions in the listener (in this case, it is fear), to make the listener implement the hortation.

The supplementary impact is carried out by a subjective interpretation, motivation of the hortation:

- Dašuta, ja kajus'! Prosti! Mne stydno! Ja hotela vernut' den'gi, no kak? < ..> Ja vsego odin raz ostupilas'! Mučalas', rydala, vse posledujuščije gody pytalas' tebe pomogat'. Nu, otpusti mne greh! (D. Doncova).

- Dashuta, I confess! I am sorry! I am embarrassed! I wanted to return the money, but how? <...> I stumbled only once! I suffered, I cried, all the subsequent years I've tried to help you. Please, purify me from my sins! (D. Doncova).

The basic impact is related to verbalization of the 'sorry' request, while the supplementary (emotional) impact is presented with the explication of the emotional state of the speaker ( $I$ confess, I am embarrassed) and the subjective evaluation of the situation (I wanted to return ..., I stumbled only once ..., I tried to help...). By performing this type of impact, the speaker repeatedly expresses request (Purify me from my sins), the success of which is predetermined by the necessity of the response emotional reaction from the listener.

Often the supplementary impact represents the specificity in the presentation of the roles of communicators with a selection of forms of hortation verbalizing.

(1) $-<\ldots>$ Daj, požalujsta, eleksir. - Eto skazka. (2) - On jest’! - Solnyško, tebe lučše pospat’! (3) - Gadina! Dlja sebja berežoš! - vpala $v$ isteriku Marta. - Mne Jadviga vsjo rasskazala! Ona tebe jego dala I spasla! - Jad k starosti umom 
slabla. (4) - A-a-a! Pravda glaza kolet! Ob’javila babušku

psihopatkoj! Zagrobastala eliksir! Daj, daj, daj! (D. Doncova).

(1) $-<\ldots>$ Please give me the elixir. - It's a fairy tale. (2) - But it exists! - Honey, you better get some sleep! (3) - You snake! You keep it for yourself! - Marta threw a fit. - Jadwiga told me everything! She gave it to you and saved you! - Jadwiga's mind weakened with age. (4) - A-ah! The truth hurts you! You called your grandmother crazy! You seized the elixir! Give it to me, give it to me, give it to me! (D. Doncova).

To express the communicative intent the addresser chooses a mitigated type of hortation, which is a request (1). Its nonemphatic nature is characterized by the token of courtesy please (Please give me the elixir), but the goal of communication is not reached. To implement the stated intention the speaker corrects the actions by transiting from a mitigated directive to the flat requirement (4), the specificity of impact of which is determined by repetition of the key phrase (give it to me, give it to me, give it to me).

This EHS can be represented as a series of actions by the addresser: 1) analysis of the situation of communication; 2) selection of the type of impact (on the metal and emotional sphere); 3) implementation of the emotional impact by expressing emotional and evaluative relationship towards a receiver ( $a$ snake); 4) selection of new categorical forms of hortation, which are requirements. The addresser changes the situation of communication by increasing the role status in order to manipulate the receiver within the frames of the communicative intent: in actualization of differences in status of the communicants, the hortation in the form of requirement demonstrates the situational right of the addresser to make the destination to perform an action. The emotional impact is carried out through the subjective interpretation of reality and is embodied in the indictment (the receiver is caught in a lie, all the receiver's arguments are not convincing). By making such an impact, the speaker predicts that the hortation is to be perceived as unappealable.

\section{CONCLUSION}

Thus, the content plane of the EPV can be represented in terms of semantic and pragmatic components of the EHS.

The semantic component is characterized by the transmitted communicative meanings of the hortation, which form the macrointention for the statements (the communicative and semantic level of the content). From this point of view, the facts can be described in the terms of speech activity and the types of the used structures. It is caused by the fact that to each communicative intention corresponds to a variable range of structures with the features of communicative meaning.

The pragmatic component is characterized in terms of efficiency and the success in the speech impact (the communicative and pragmatic level of the content). Since the verbal behavior of the speaker in the pragmatic aspect is traditionally regarded as the choice of the way of expression of the communicative intention, specific features of performance of the emotive component in the hortation structure should be regarded in terms of the communicative behavior of the addresser: to plan the interaction of communicants and to monitor the process of communication. The speaker set an objective of communication (implementation of the hortative macro-intention) and reaches it in the most optimal way for the situation.

\section{REFERENCES}

[1] Ju. Kadyrkova, "Struktura emotivnyh pobuditel'nyh vyskazyvanij v kommunikativno-pragmatičeskom aspekte", Vestnik St. Peterburgskogo universiteta, 2009, vol. 9, No. 4, pp. 80-86.

[2] S. Ionova. Emotivnost' teksta kak lingvističeskaja problema. Volgograd, 1998.

[3] A. Maslova. Vvedenije v pragmalingvistiku. Moskva, 2007, p 47.

[4] I. Shatunovskij. "6 sposobov kosvennjgj vyrazhebija smysla" Semantika I pragmatika jazykovyh jedinic. Kaluga, 2004. 